\title{
ПРОЕКТУВАННЯ ЕКСПЕРТНОЇ СИСТЕМИ «МОНІТОРИНГ РИНКУ ПРАЦІ» ДЛЯ ФОРМУВАННЯ ДЕРЖАВНОГО ЗАМОВЛЕННЯ НА ПІДГОТОВКУ ФАХІВЦІВ
}

\begin{abstract}
Здійснено теоретико-методологічний аналіз складових ринку прачі, проаналізовано взаємозв'язок професійної освіти та становлення людського капіталу, визначено політику реалізації системи управління якістю підготовки фахівців, визначено вимоги до сучасного фахівия, висвітлено складові експертної системи "Моніторинг ринку праці», вивчено питання державного замовлення на підготовку фахівиів.

Ключові слова: експертна система, блок вводу-виводу, блок даних, аналітичний блок, база знань, людський капітал, ринок праці, інфраструктура ринку праці, трудові ресурси, моніторинг ринку праці, державне замовлення на підготовку рахівиів.

Осуществлен теоретико-методологический анализ составляющих рынка труда, проанализирована взаимосвязь профессионального образования и становления человеческого капитала, определена политика реализачии системь управления качеством подготовки специалистов, определены требования к современному специалисту, освещень составляющие экспертной системы «Мониторинг рынка труда», изучены вопросы государственного заказа подготовку специалистов.

Ключевые слова: экспертная система, блок ввода-вывода, блок данных, аналитический блок, база знаний, человеческий капитал, рынок труда, инфраструктура рынка труда, трудовые ресурсы, мониторинг рынка труда, государственный заказ на подготовку спеииалистов.
\end{abstract}

Theoretical and methodological analysis of the components of the labor market are carried out, the relationship of vocational education and human capital formation is analyzed; policy implementation system of quality management training, determined by the requirements of the modern specialist, is defined; highlights the components of the expert system, «Monitoring the labor market», the issues the public order training are explored.

Key words: expert system, input-output block, the block of data, analytical power, knowledge base, human capital, labor, infrastructure, labor market, human resources, monitoring of the labor market, the state order for training.

Швидкі темпи розвитку інформаційних технологій створюють умови для глобальної автоматизації виробництва, що зменшує штат персоналу. Проте, незважаючи на це, головним чинником формування та розвитку інноваційної економіки залишається людський капітал. Економічний розвиток і стабільність існування як суспільства в цілому, так і окремого індивіда безпосередньо залежить від сукупності його знань, умінь і навичок. Сформованість інтелектуальних якостей характеризують знання, а їх рівень - відповідний навчальний заклад з наданням обраного фаху. Однак, як відомо, що здобутий диплом не гарантує працевлаштування за ним. Так, А. Сгоршина зазначає, що лише 60 \% кваліфікованих фахівців працюють за фахом, інші влаштовуються на посади службовців і працюють простими робітниками. Це, у свою чергу, викликає зворотну реакцію - слугує поштовхом до зниження соціального престижу освіченості й інтелекту.

Можливість проведення моніторингу з метою аналізу та прогнозування ринку праці дозволить уніфікувати його потреби з відповідною підготовкою фахівців. Такий підхід покликаний допомогти розв'язати питання ефективного становлення людського капіталу, що сприятиме постійному забезпеченню якості освіти.

Підписавши стратегію державної кадрової політики на 2012 - 2020 р., Президент України В. Янукович, таким чином визначив iї реалізацію через ефективну систему формування державного замовлення на підготовку кваліфікованих робітничих кадрів і фахівців 3 вищої освіти для задоволення потреб ринку праці; впровадження електронного управління; удосконалення системи прогнозування розвитку кадрового потенціалу. «Прогнозування і планування ринку праці, зокрема держзамовлення, - це складна економіко-математична задача класу завдань стратегічного планування, яка потребує серйозного наукового розроблення, 3 математичним підгрунтям, ураховуючи сотні змінних з великою невизначеністю, в бездоганній статистичної базі тощо» [16].

Отже, виникає необхідність у створенні експертної системи моніторингу ринку праці, яка на основі існуючих даних, визначених умов дозволить спрогнозувати необхідну кількість фахівців, запропонувавши рекомендації до перепідготовки існуючих.

Вищеозначеними проблемами, їх вивченням і дослідженням займаються науковці різних категорій - соціологи, економісти, програмісти, освітяни та ін.

Так, принципи становлення та формування людського капіталу, структурний аналіз, економічну та соціальну ефективність професійної освіти пов'язують 3 іменами Г. Беккера, Я. Гомберга, Дж. Кендрика, С. Кузнеца, Р. Лукаса, Дж. Милера, Р. Смита, Р. Солоу, И. Фишера, Т. Шульца.

Отримані висновки і механізми регулювання важливі для подальшого формування стратегії, але, як зазначає Чун Чже Вон, їх дослідження передбачають підходи до формування людського капіталу в 
умовах або вільної конкуренції, або розвиненої ринкової економіки, що не дозволяє використовувати отриманні ними висновки та рекомендації для країн з економікою затяжного періоду [20]. 3 огляду на це Р. Деккушевим досліджено процеси державного регулювання відтворення трудових ресурсів [3]; М. Пінтаєвою - розвиток інфраструктури ринку праці в регіоні. Дослідниця розглядає взаємодію між суб'єктами трудових відносин й інститутами соціально-трудової сфери з метою забезпечення балансу попиту та пропозиції робочої сили [12].

Для побудови експертної системи необхідні вхідні дані, на основі яких буде здійснюватись подальший аналіз, прогноз та інформаційне моделювання. Дослідженням методик комплексного статистичного аналізу ринку праці займалась Т. Саричєва [13].

Підгрунтям для проектування та впровадження інформаційних систем слугували праці Ю. Ізбачкова, В. Петрова [6], І. Матієнко-Зубенко [4], В. Ситника [15], Г. Титоренко Л. Терещенко [18].

Задля вивчення практичного досвіду з проектування та організації цього процесу, - опису предметної галузі та іiі інформаційних потоків, а також уникненню проблем, пов'язаних із результатами впровадження, у наукових дослідженнях розв'язано різні завдання управління в складних галузевих організаційно-технічних системах. Так, для ефективної організації роботи над розробленням системи, для зниження затрат праці на розроблення систем у зв'язку з можливістю автоматизованого вибору найбільш релевантних інформаційних моделей, звернемо увагу на дослідження О. Нечипоренко [10]. Вивчаючи системний підхід розроблення програмного коду, роботи із внутрішніми та зовнішніми базами даних для експертної системи, виокремимо працю В. Добряка [4], А. Ідіатулліна [5]. Їхні наукові висновки дозволяють автоматизувати етапи логічного проектування, створивши інформаційну модель експертної системи.

Мета статmi - визначити складові модулів експертної системи моніторингу ринку праці.

Ускладнення соціально-економічних умов розвитку суспільства зумовили вимоги як до майбутнього фахівця, так і до освіти в цілому. Конкретизація вимог споживачів (замовників держави, підприємств, індивідів) визначають методи управління якістю освіти, зокрема - внутрішню реорганізацію та реструктуризацію ВНЗ, створення нових спеціальностей тощо.

Експертна система моніторингу ринку праці покликана допомогти проводити збалансовані реформи ВНЗ регіону, з урахуванням реальних потреб підприємств області. Під експертною системою (ЕС) будемо розуміти програму, яка використовує знання фахівців (експертів) про деяку конкретну вузько спеціалізовану предметну галузь і в їі межах цієї здатна приймати рішення на рівні експерта-професіонала.

3 метою побудови інформаційної моделі моніторингу ринку праці визначимо основні блоки експертної системи. За основу нами взято: блок вводу-виводу; блок даних; аналітичний блок; база знань.

Діалоговий режим блоку вводу-виводу доцільно організувати через мережу Інтернет за допомогою Веб-інтерфейсу, що дозволить працювати в режимі реального часу, забезпечуючи обмін пакетними даними між різними регіонами. Таку ідею підтримує і В. Калініна [8], зазначаючи під час проектування інформаційно-аналітичної системи «вигідність» для інтерфейсу web-cайту, який забезпечує доступ до бази даних через WEB Server та ГIC Server. Зазначимо, що сайт може виступати в ролі web-сервісу, оскільки для виконання задач аналітико-прогностичного характеру. Оскільки молодь складає багаточисельну частку користувачів, то одним 3 необхідних критеріїв виступає організація доступу до експертної системи з мобільних пристроїв, інтернет-планшетів. Для цього у нагоді стане розробка функціонального додатку для Android, iPhone або iPad платформ.

Для організації блоку даних та аналітичного проведемо аналіз понять, які використовуються в дослідженні. Взаємозв'язок між якими дасть змогу обгрунтувати логіку оброблення даних та управління ними; визначити потенційних користувачів системи. Розділимо терміни на категорії. Так, до економіки праці віднесемо поняття: ринок праці, людський капітал, трудові ресурси та регулювання відновлення трудових ресурсів, інфраструктура ринку праці; до менеджменту освіти формування державного замовлення на підготовку фахівців, якість освіти, система управління якістю освіти.

Сфера формування попиту і пропозицій на робочу силу визначає ринок праці. Основою цієї сфери виступають людський капітал і трудові ресурси, відновлення яких є важливим питанням для розвитку економіки.

Людський капітал формується внаслідок оволодіння знаннями, уміннями і навичками, а також за умови соціального розвитку людини. Частину населення, яка за фізичним розвитком, надбаній освіті, професійно-кваліфікаційним рівнем здатна займатися суспільно корисною діяльністю, називають трудовими ресурсами.

Регулювання трудових відносин, максимальної продуктивності зайнятості населення, ефективне функціонування ринку праці здійснює держава через побудову його інфраструктури, яка складається як $з$ державних, так і недержавних служб.

Блок даних - моніторинг ринку праці має виконувати такі завдання: 1) збирати інформацію щодо руху робочої сили (наймання, звільнення, міграція тощо); 2) виявляти кількість зайнятих, частково 
зайнятих і безробітних; 3) з'ясовувати рівень мобільності праці, оптимальний рівень і вид мобільності; 4) аналізувати зміни у структурі зайнятості та структурі продуктивності праці; 5) з'ясовувати збалансованість розподілу населення на зайнятих, частково зайнятих, тимчасово вивільнених і безробітних [1].

Таким чином, блок даних передбачає такі складові: банк вакансій, банк трудових ресурсів (даних фахівців, яких підготували за окреслений термін ВНЗ), класифікатори фахівців.

Розкриваючи складові аналітичного блоку, зазначимо, що його функціональне призначення спрямоване на організаційно-економічне регулювання процесу формування трудових ресурсів. Отже, метою створення такого блоку є визначення та надання рекомендацій (концепцій розвитку) щодо оптимізації процесу управління якістю освіти, формування державного замовлення на підготовку кваліфікованих робітників та фахівців.

Таким чином, складові аналітичного блоку поділяються на складові економіки ринку праці та менеджменту якості освіти. В контексті першої складової зазначимо, що основою для складання бази знань $є$ моніторинг ринку праці та визначення ії інфраструктури.

Моніторинг забезпечує систематичний контроль за станом розвитку деяких процесів, іншими словами - це збір аналітичної інформації про об'єкт. Проводять його 3 метою при-йняття управлінських рішень, відповідно до об'єкта або процесу, на який він спрямований. Так, моніторинг ринку праці допомагає усуненню проблем функціонування та його прогнозування, проведення активної політики щодо регулювання попиту та пропозиції трудових ресурсів, формування людського капіталу (замовлення на підготовку фахівців), тобто сприяє підтримці соціальноекономічного розвитку країни. Даними щодо моніторингу ринку праці в Україні можуть володіти як незалежні експерти i науковці, так i органи виконавчої влади, такі як державний комітет статистичних даних, Міністерство економіки. Ці дані матимуть статус інформаційних ресурсів для блоку даних експертної системи.

Для ефективного управління якістю підготовки фахівців необхідно звернути увагу на державну політику управлінням у галузі вищої освіти. Формування державного замовлення на підготовку фахівців, відповідно до Закону «Про вищу освіту», здійснює Кабінет Міністрів України. Через систему органів виконавчої влади у межах своїх повноважень видає нормативно-правові акти 3 питань вищої освіти, зокрема, накази «Щодо формування пропозицій до обсягів державного замовлення», «Про формування обсягів державного замовлення на підготовку робітничих кадрів у професійно-технічних навчальних закладах», «Про державне замовлення на підготовку та випуск фахівців з вищою освітою».

Критерії, за якими формується державне замовлення, визначено наказом Міністерством економіки від 03.10 .2005 р. № 314 «Про затвердження критеріїв формування державного замовлення на поставку продукції для державних потреб» (зі змінами внесеними 17.09.2009 г. № 1024 [16].

Визначаючи механізм формування державного замовлення звернемо увагу, що запит на підготовку фахівців формують навчальні заклади, спираючись на власну матеріально-технічну базу. Дані передають до міністерства, якому підпорядковуються. Після внесення коректив, сукупність цих даних подається до Міністерства економіки. Останнє, володіючи даними попиту трудових ресурсів на ринку праці, затверджує нормативний документ про державне замовлення на підготовку та випуск фахівців $з$ вищою освітою.

Хоча є супротивники такого механізму підтримки системи підготовки фахівців, але необхідно зазначити, що для країн 3 перехідною економікою підтримка освіти виступає одним 3 варіантів іiі збереження, що $є$ однією з важливих елементів забезпечення соціальної стабільності, а також збереження наукових кадрів та нормальне функціонування як вищих навчальних закладів, так $\mathrm{i}$ науково-дослідних інститутів, що входять до їх структури.

У такому випадку вища освіта стає дотаційною, і як зазначає П. Полянський, І. Зволинський, такий механізм не дієвим, він «не визначає потреби в кадрових ресурсах, а також не визначено рівень вимог до фахівців» [3]. На неефективну систему державного замовлення звертає увагу і Колегія Рахункової палати України, що вказує на такі проблеми: «відсутність механізму працевлаштування випускників ВН3; незабезпечення дотримання законодавчих норм про співвідношення прийнятих на навчання за держзамовленням і за контрактом; відсутність стандартів вищої освіти з урегулювання нормативів матеріально-технічного, фінансового та іншого забезпечення вищих навчальних закладів, зокрема методик розрахунку вартості підготовки фахівця» [8].

Таким чином, у наявності маємо характерні ознаки неформалізованої задачі: помилковість, неоднозначність, неповнота і суперечливість знань про проблемну галузь; велика кількість можливих варіантів рішень та обмежень поставленої задачі; наявне використання алгоритмів нечіткої логіки тощо.

Саме завдяки аналітичному блоку експертна система здатна виступати важливим елементом у процесі: 1) обгрунтування динаміки зайнятості та безробіття; 2) аналізу макро-, мезо- та мікроекономічних явищ, які впливають на зайнятість, умови праці, вподобання працівників і роботодавців; 3) контролю за станом ринку праці, пропорціями зайнятих i безробітних; 4) прогнозування критичних явищ на ринку праці та планування дій із їх запобігання та усунення; 
5) оцінки бюджетного розподілу навчальних місць відповідно до матеріально-технічної бази університету та регіональних потреб; 6) формування мінімального рівня прийому абітурієнтів, який дозволить забезпечити соціальну стабільність у регіоні; 7) розрахунку собівартості навчання для кожного регіону з урахуванням його економічного розвитку.

У свою чергу, підгрунтям знань виступатимуть правила аналізу інформації - ряд економічних моделей регулювання трудових відносин, ряд системних моделей, що використовуються для аналізу та розв'язку проблем, які склались нині в системи вищої освіти.

Проведений огляд літератури дав змогу з'ясувати проблеми підготовки кадрів, зокрема стан та перспективи розвитку ринку праці, формування трудових ресурсів та людського капіталу.

Актуальними напрямами подальшого розроблення окресленої проблеми є вивчення механізму формування ринку праці; проведення аналітичної оцінки кількісного запиту підготовки та працевлаштування фахівців, вивчення проблеми довгострокового аналітичного прогнозу щодо формування державного замовлення на підготовку кваліфікованих робітників та фахівців.

\section{Література}

1. Википедия «Свободная энциклопедия» / [Електронний ресурс].-Режим доступу до словника:

http://ru.wikipedia.org/wiki / Человеческий капитал. 2. Википедия «Свободная энциклопедия» / [Електронний pecypc]. - Режим доступу до словника: http://ru.wikipedia.org/wiki / Трудовые pесурсы 3. Деккушев Р. Б. Организационнно-экономические отношения и процессы государственного регулирования воспроизводства трудовых ресурсов депресивных территорий : автореф. дис. на соискание уч. степени канд. экон. н. : спец. 08.00 .05 «Экономика и управление народным хозяйством (економика труда)» / Деккушев Р. Б. - Ростов-наДону, 2012. - 27 с. 4. Добряк П. В. Проектирование информационных систем в рамках объединенного объектно-реляционного подхода : автореф. дис. на соиск. уч. степени канд. тех. н. : спец. 05.13. 21 «Системы автоматизации проектирования (по отраслям)» / Добряк П. В. - Екатеринбург, 2007. - 27 с.

5. Идиатуллин А. Р. Инструментарий проектирования информационно-аналитических систем управления на основе онтологических моделей и методов формализованного представления предметной области организации: автореф. дис. ... канд. экон. наук : спец. 08.00.13 «Математические и инструментальные методы экономики» / Идиатуллин А. Р. - М., 2011. - 27 с. 6. Избачков Ю. С. Информационные системы: учебник для вузов / Ю. С. Избачков, В. Н. Петров. - СПб. : Питер, 2006. - 656 с. 7. Информационные системы в економике: учебник для вузов. / [под ред. Г. А. Титоренко]. - 2-е изд., перераб. и доп. - М. : ЮНИТИ-ДАНА, 2008. - 463 с.

8. Калинина В. В. Проектирование информационно-аналитической системы мониторинга регионального рынка труда: автореф. дис. ... канд. экон. наук : спец. 08.00 .13 «Математические и инструментальные методы экономики» / Калинина В. В. - М., 2006. - 26 с. 9. Менеджмент, маркетинг и экономика образования: учебное пособие / [под ред. А. П. Егоршина]. - Н. Новгород : НИМБ, 2001. - 624 с. 10. Нечипоренко О. А. Проектирование информационных систем с использованием метода основанного на прецедентах : автореф. дис. ... канд. тех. наук : спец. 05.13.01 «Автоматизированные системы управления - Проектирование Автоматизация» / Нечипоренко О. А. - Краснодар, 2003. - 27 с. 11. Палиця О. Моніторинг ринку праці як складова системи державної діагностики попиту та пропозиції робочої сили / О. Палиця // Наукові праці МАУП. - 2010. - Вип. 1(24). - С. 83-89. 12. Пинтаева М. Ю. Развитие инфраструктуры рынка труда в регионе : автореф. дис. ... канд. экон. наук : спец. 08.00 .05 «Экономика и управление народным хозяйством (экономика труда)» / Пинтаева М. Ю. - М., 2009. - 28 с. 13. Сарычева Т. В. Статистический анализ и прогнозирование состояния рынка труда Республики Марий Эл : автореф. дис. ... канд. экон. наук : спец. 08.00.12 «Бухгалтерский учет, статистика» / Сарычева Т. В. - М., 2006. - 27 с. 14. Система госзаказа неэффективна // Счетная палата: [Електронный ресурс]. - Режим доступа: http://ru.osvita.ua/vnz/news/26597/ 15. Ситник В. Ф. Інформаційні системи і технології в економіці / В. Ф. Ситник. - К., 2002. 16. Стратегія державної кадрової політики на 2012-2020 роки від 01.02.2012 № 45/2012 / [Електронний ресурс] http://zakon2.rada.gov.ua/ : Режим доступу http://zakon2.rada.gov.ua/ laws/show/45/2012\#n7. 17. Страшная тайна госзаказа [Електронний ресурс]// «Зеркало недели. Украина». - №33, 16 сентября 2011 / Л. Суржик, О. Онищенко. - Режим доступу:http://zn.ua/ EDUCATION/strashnaya tayna_goszakaza-87981.html. 18. Терещенко Л. О. Інформаційні системи і технології в обліку: навч. посіб. / Л. О. Терещенко, І. І. Матієнко-Зубенко. - К. : КНЕУ, 2004. - 187 с. 19. Тимченко В. В. Системы менеджмента качества в образовании / В. В. Тимченко, С. Ю. Трапицын, М. В. Жарова. - СПб. : Издво РГПУ им. А. И. Герцена, 2008. - 170 с. 20. Чун Чже Вон. Рынок труда и трудовая миграция в России в контексте глобализации : автореф. дис. ... канд. соц. наук: спец. 22.00 .03 «Экономическая социология и демография» / Чун Чже Вон. - М., 2008. - 28 с. 